\title{
Changes In The Bargaining Power Of Chinese Migrant Workers And The Factors Enhancing Laborers' Power
}

\author{
Han Ping, The School of Management, Xi'an Jiaotong University \& Key Lab of Ministry of \\ Education for Process Control \& Efficiency Engineering, China \\ Bahaudin G. Mujtaba, Nova Southeastern University, USA \\ Chen Xue, The School of Management, Xi'an Jiaotong University, China
}

\begin{abstract}
The "shortage of migrant workers" phenomenon is not only a reflection of the changing concept of occupation for Chinese migrant workers, but it also increases job opportunities for such workers. Migrant workers fight for higher wages through strikes and collective negotiations. These changes reflect the enhancement of the bargaining power of Chinese migrant workers.

This paper explores the factors that enhance Chinese migrant workers bargaining power, uses a fuzzy comprehensive evaluation based on the analytic hierarchy process to assess the effect of various factors, and analyzes the positive and negative effects of enhancing the bargaining power. Finally, this paper predicts changes in the bargaining power of Chinese migrant workers and provides corresponding recommendations to protect their advantages.
\end{abstract}

Keywords: Chinese Migrant Workers; Bargaining Power; Fuzzy Evaluation; Analytic Hierarchy Process

\section{INTRODUCTION}

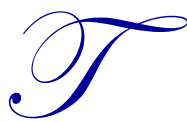

he implementation of reforms and the process of opening up in China started the rapid industrialization and urbanization in the country. Thus, a large number of farmers came into the city as workers and formed a huge special group known as migrant workers. Chinese migrant workers have been promoting the development of various sectors of the national economy and have made important contributions to the modernization of China. The country has more than 200 million migrant workers, and this number continues to rise. Therefore, migrant workers are gaining a collective personality and have become the main components of industrial workers in China (Ping, Mujtaba, Whetten, \& Wei, 2012). Both the "migrant worker tide" in the 1980s and the "labor shortage" in recent years have demonstrated the impact of migrant workers on the Chinese labor market. This shift resulted from the demand of migrant workers for a change in their wages. Income problems of migrant workers have caught the attention of government departments and the academe because the income of the former is not synchronized with the economic development of China. The low income of migrant workers, irrational revenue structure, unfair social distribution, and lack of share in the benefits of the Chinese economic development made the income of migrant workers an important constraint factor in the industrialization, urbanization, and coordinated development of urban and rural processes in the country.

In recent years, the government and the community have attached great importance to the wage problem of migrant workers, with wages eventually improving to some extent. Since the beginning of the 21 st century, the Chinese urban labor market emerged as a clear intergenerational replacement, with migrant workers born in the 1950s and 1960s gradually moving out of the urban labor market and the new generation of migrant workers born after the 1980s gradually becoming the main component of the urban labor market. The new generation of migrant workers from rural areas who were born in the 1980s and whose ages are between 16 and 28 years old started working or conducting business in cities in the late 1990s or the early 2000s. Most of them entered the city as workers after graduation, having a higher level of education, no farming experience, mostly unmarried, being lifted 
out of the social life in rural areas, and having close ties to city life (Zhou \& Wan, 2009). Their upbringing, life experiences, values, and future expectations are different from those of their parents, as older-generation migrant workers live by their thrifty and industrious characteristics, can survive in factories, and consider the rural areas their last destination. However, the new-generation migrant workers, who are the consumer type and enjoy city life, do not passively accept lower wages and have higher expectations on their employment environment and wages.

\section{CHANGES IN THE BARGAINING POWER OF MIGRANT WORKERS}

Wage negotiation is a process in which two sides, under conditions of asymmetric information, bargain with each other according to their respective expectations. With the current system of wage bargaining model in China based on the bargaining theory, workers have not bargained for wages and employment conditions with enterprises directly, but they can make their own choices whether to accept the wages that enterprises offer (Lu, 2004). Thus, firms have to account the behavior of employees during wage and employment optimal decisions. Existing studies on the bargaining power of employees and workers represent their bargaining power with the general level of wages or income (Svejnar, 1986). At the same time, the more job opportunities and the improvement of employment autonomy demonstrate the enhancement of the bargaining power of employees.

The bargaining power of the new generation of migrant workers has clearly improved compared with the older-generation migrant workers. The improvement of the bargaining power of migrant workers is demonstrated mainly in two aspects.

First, migrant workers have more job options and their employment autonomy is consequently enhanced. The "labor shortage" phenomenon occurred in the local coastal areas of China in 2003. After eight or nine years, the previous "local labor shortage" developed into the "overall labor shortage." Research by the Human Resources and Social Security of Guangdong Province indicates that enterprises in Guangdong lacked one million workers in 2012 (Wang, 2012). The relatively large employment gap in Shunde District has enabled job seekers to choose from three to four jobs available. Different degrees of "recruitment difficulties" also emerged in the Pearl River Delta, Yangtze River Delta, the Bohai Sea, and other important economic regions in China as well as in large migrant workersexporting provinces. The employment of migrant workers shifted from "workers find factory" to "factory find workers." As the main labor force, migrant workers can improve their income fast, which is a major boost in changing the irrational revenue structure. From this perspective, the "labor shortage" phenomenon of migrant workers increases more job opportunities for migrant workers and enhances their bargaining power with employers, as migrant workers have more options and their job autonomy has been more enhanced.

Second, the wages and income of migrant workers have increased. In May 2010, a number of workers in the Foxconn, a Taiwanese factory located in Shenzhen, committed suicide (Foxconn is the largest exporter in China, with more than 270,000 employees in Shenzhen alone). The workers who committed suicide were migrant workers and production workers in labor-intensive enterprises. The company subsequently announced that it would double the wages after a three-month trial period. In June, Honda suppliers held a series of strikes. Although the number of striking workers of the Honda Group did not reach 2000 and most of the strikes did not last more than one week, the workers were able to succeed in their endeavor, as their working condition was improved and their salaries were increased. In the Honda Lock Factory in Guangdong, workers demanded a wage increase of 70 percent but were given an increase of 28 percent instead (Oxford Economic Report, 2010). These strikes resulted in employees receiving substantial increase in wages, as the solution to the strikes in general was a wage increase of 20 percent to 25 percent. In 2011, data from the Employment Management Services Bureau in Yiwu City indicate that the pressure of "labor shortage" has caused the basic wages of ordinary workers in factories to reach 1500 yuan to 1800 yuan. In several enterprises, the security wage of ordinary workers even reached more than 2000 yuan (Zhang, 2011). On January 1, 2013, a total of 24 provinces in China increased the minimum wage standards, with Shenzhen providing the highest monthly minimum wage (1 500) followed by Zhejiang (1 470) and Shanghai (1 450). Beijing has the highest minimum hourly wage standard (15.2), followed by Xinjiang (13.4) and Shenzhen (13.3) (sina news, 2012).

The improving awareness on the collective negotiations of migrant workers and the growth of labor union power influence the bargaining power of the workers. Low wages triggered strong dissatisfaction among migrant 
workers, causing labor relations to become tense. In November 2009, the labor unions in Xianduan Jingmi (a Chinese corporate) issued a collective negotiation offer to the employer side, particularly bargaining on wage increase. The two sides agreed in 2010, with frontline employees receiving a wage increase of 10 percent and nonfrontline staff receiving a wage increase of 8 percent. The Yantian labor union took a similar action. For 10 years, three growth curves impressed the people of Yantian: the throughput of the port is a rising curve, the corporate profit is a rising curve, but the wages of workers is a horizontal line. The efforts of the union resulted in the enterprise finally agreeing to increase the wages of workers.

Overall, the "labor shortage," strikes, and collective union negotiations improved the wages of migrant workers and enhanced autonomous employment. The salary increase tide has subtly enhanced the bargaining power of migrant workers. However, the bargaining power of migrant workers was restricted in several periods and regions. For example, employment growth quickly rebounded and increased from 0.7 percent in the first quarter of 2009 to 3.8 percent in the first quarter of 2010. In the past few quarters, nominal wage growth had been hovering at approximately 13 percent. The acceleration of the Chinese Consumer Price Index during the same period caused real wage growth to fall to 10.6 percent in the first quarter of 2010 from 14.2 percent in the third quarter of 2009. This phenomenon may be related to price fluctuations or short-term fluctuations in the economy. In general, the wages of migrant workers and their bargaining power have improved. Therefore, this paper focuses on the enhancement of the bargaining power of the migrant workers.

\section{FACTORS ENHANCING THE BARGAINING POWER OF MIGRANT WORKERS}

This paper analyzed 24 English papers, eight Chinese papers, and 13 news stories and reports and extracted a number of factors that enhance the bargaining power of Chinese migrant workers. The materials indicate that only a few local studies exist on the bargaining power of migrant workers or ordinary domestic laborers, whereas other countries have more studies on the same subject but are based more on foreign social context and focused more on urban workers. Chinese migrant workers have different characteristics and experience from foreign workers, and the change in bargaining power and influencing factors of the former are also different from workers in other countries.

The authors of this study also conducted personal interviews with 10 migrant workers, 10 employers, 10 union officials, and 10 government staff members. Results of the interview were included in the discussion of the factors that enhance the bargaining power of migrant workers. In this study, using a semi-structured interview method, which is unlike the structured approach that is restricted by the interviewer's answer and prevents unstructured data statistics, the interviews focused on the following issues: (a) Understand relevant background and demographic information about the interviewees; (b) Understand the view of interviewees on the concept of bargaining power; (c) Understand what the interviewees consider as the factors that enhance the bargaining power of migrant workers; (d) Require the interviewees to determine which among the factors they shared are more important; (e) Understand what the interviewees consider the enhancement of the bargaining power of migrant workers.

\section{Migrant Workers}

Quality and Human Capital Improvement of Migrant Workers

The quality of heterogeneity of laborers results in incomplete competition in the labor market; the higher the quality of workers, the higher is the corresponding wage (MacLeod \& Maleomson, 1993). The study also indicates that when the quality of workers is controlled, wage differentials and the wage premium phenomenon will disappear (Yankow, 2006). Differences in the human capital of workers are mainly decided by innate endowment and their education level (Xue, 2008). A survey conducted by the Guangzhou Human Resource Market Service Center indicates that qualifications and skills of the new generation of migrant workers have improved to a certain extent; their job choices are relatively broader so that most of them are not interested in general work; and handsclass posts, jobs, and treatment provided by the traditional manufacturing industry have been unable to attract them. Relevant empirical research indicates that the higher the educational and skill level of workers, the higher is the level of their wages. Table 1 presents a comparison the between two generations of migrant workers in the eastern region in China. 
Table 1: Comparison of Educational Level between Two Generations

\begin{tabular}{lccc}
\hline Educational Level & Primary and Lower & Junior High School & High School and Above \\
\hline Old Generation & $36.76 \%$ & $43.4 \%$ & $19.84 \%$ \\
New Generation & $7.44 \%$ & $51.06 \%$ & $41.5 \%$ \\
\hline
\end{tabular}

Enhancement of Group Influences of Migrant Workers

With the continuous development of the economy and urbanization in China, migrant workers play a more important role in the economic construction and the development of urbanization in the country. The current share of the tertiary industry in China, especially the service sector in the economic and industrial structures, is growing and the demand for labor is increasing. The tertiary industry, and not just the traditional manufacturing and construction industries, needs a large number of migrant workers, especially the service sector. The economic development in China cannot be disassociated from the hard work of migrant workers. The effects and roles of Chinese migrant workers are currently more prominent. Therefore, the issue of migrant workers has attracted the attention of enterprises, government, and social institutions. From a theoretical point of view, this kind of influence of Chinese migrant workers groups is derived from their mass production and creativity. Moreover, the reason why Chinese migrant workers play an important role in the economic development of China is that such groups in the labor process or human capital formation process can produce a collaborative power, which is not a simple sum of individual collaborative forces but a multiplier effect (Leap \& Grigsby, 1986).

\section{Increasing the Awareness on Collective Bargaining}

Chinese migrant workers exhibit a remarkable characteristic when looking for a job: collective behavior. The reason for this behavior is that migrant workers are homogeneous; people from the same village have close links to each other (Zhou \& Zhang, 2005). Migrant workers generally seek jobs in cities by asking help from fellow townsmen and relatives, and find work in droves. Chinese migrant workers from the same village usually work in the same factory, which is a very common phenomenon in China. One migrant worker not only can bring a group of migrant workers to work there but also take away a group. Chinese migrant workers actually conduct collective bargaining with enterprises, either accepting the wage of employers or exiting collectively. In the current era of "shortage of migrant workers," this kind of collective bargaining behavior of migrant workers is powerful. Moreover, the awareness on collective bargaining of Chinese migrant workers is increasing so enterprises are concerned about their collective exit. In this context, the collective bargaining power of migrant workers has improved significantly.

\section{Information Superiority of Migrant Workers}

The information superiority mentioned in this paper refers to the understanding or being familiar with a variety of related information such as businesses, jobs, and policies, among others (Svejnar, 1986). More information at one's disposal strengthens bargaining power. The Chinese government is particularly concerned about the issue of migrant workers and takes several policies and measures to focus its efforts on resolving the issue of migrant workers. Chinese migrant workers pay attention to relevant national policies and institutions, such as the Chinese governmental regulation of minimum wage standard and the prohibition of wage arrears of migrant workers. Using these regulations and policies as weapons, Chinese migrant workers have legal basis to protect their legitimate rights and interests in negotiations with enterprises. The improvement of cultural and educational levels has equipped migrant workers with a certain understanding of business and financial knowledge. The government requires listed companies to make public operational and financial information so that migrant workers can infer their acceptable wage level. Migrant workers who have a better understanding of the information on wage bargaining with enterprises have the ability to fight for higher wages.

\section{Enterprises}

Type of Business (Dependence on Migrant Workers)

The dependency on migrant workers of different enterprise is not the same (Zhong, 2003). The core competitiveness of several enterprises mainly depends on capital; a number depend on technologies, whereas others 
depend on labor. For labor-intensive enterprises, labor is the most important productive factor, and the absence of a large number of workers directly affects the production. The current development of the secondary industry in China, with the development of the manufacturing sector, is still going strong, as the demand for ordinary labor remain exuberant. Migrant workers form the main body of ordinary labor. As such, they are in an advantageous position to negotiate with employers, especially in the production and manufacturing industries, because of the dependency of the latter on the former.

\section{Loss Cost of Migrant Workers}

The loss of migrant workers in China has a significant characteristic called collective loss or collective resignation. The employer's ability to afford business risk is a dominant aspect; it has strong negotiating power in the bargaining between employers and employees (Shi, 1995). If enterprises that demand more migrant workers are able to assume collective losses (i.e., recruitment, training, and technical losses) and the potential production stoppage caused by migrant workers loss, then such enterprises have higher bargaining power than the migrant workers. If companies cannot shoulder the losses, then these companies have a weak position when negotiating with migrant workers.

\section{Development Stage of Enterprises}

The bargaining power of migrant workers in the different development stages of the enterprise is different (Sheng \& Yu, 2003). China is still a developing country, and a gap still exists at the economic level between it and the other advanced countries in the world. The economic structure of China is not perfect, as the proportion of the tertiary industry is still not high and the economy relies more on the development of the secondary industry. After three decades of development since the reform and opening up has entered a mature stage, the secondary industry, especially the manufacturing sector, tends to retain mature migrant workers labor. Therefore, enterprises are considered the weak side when negotiating with migrant workers. In the tertiary industry, especially the service sector that started relatively late and most businesses that are still in their formative years, the role of the labor force is increasing, providing several advantages for migrant workers over the employers.

\section{External Environment}

\section{Supply and Demand in the Labor Market (Competitive Conditions)}

The wage bargaining power of migrant workers is determined by the supply and demand of the labor market (Pacitti, 2009). The level of bargaining power depends on the scarcity of input factors. Extreme scarcity and the non-substituting factor certainly bring powerful negotiating force to the owner. However, if a certain resource has adequate supply, then the owners cannot increase their power in the negotiating process. The current nationwide "shortage of migrant workers" in China not only takes place in the Pearl River Delta, the Yangtze River Delta, and the Beijing-Tianjin region but also in several central and western regions in the country. The supply of Chinese migrant workers is less than the demand and supply of mature migrant workers with technology-related skills. Experience is especially in shortage. Moreover, the situation of short supply of Chinese migrant workers brings about a relatively strong bargaining power for migrant workers.

\section{Local Industrial Concentration}

If industries are relatively concentrated in certain places only, then hundreds or even thousands of the same types of enterprises as well as the same types of employees (e.g., engineers and technicians) will exist, which is conducive in enhancing the negotiating power of employers (Bental \& Demougin, 2010). For example, the tie production enterprises in Shengzhou of Zhejiang Province number in the thousands, with the number of workers reaching more than 30 000. If an employee leaves the enterprise, the supervisor will find it easy to look for a replacement. In other regions where only a limited number of tie factories are present, expect that employees in this factory, even if they have limited skills, will be treated very well by the supervisor because of the limited supply of employees in the vicinity. In this case, employees have strong bargaining power. 


\section{Role of Labor Unions}

According to the collective wage bargaining theory, the presence of labor unions has enabled wages to be mainly decided through collective bargaining agreements between the labor unions, which represent workers, and the employers (Dutt \& Sen, 1997). In the face of the long-time dominance of business owners, the power of Chinese migrant workers dispersed. They do not have the requirements for wage bargaining and lack the channels to protect their rights. Well-organized labor unions can help Chinese migrant workers to bargain for higher wages, especially when they have a certain amount of leverage, such as the threat of strikes. Union membership has a significant role in the wages of migrant workers, and it helps bring about more than 10 percent of the wage premium (Chen \& Chen, 2011). Chinese migrant workers spontaneously organize to unite or join a union through legal means to improve self-organization. Collective bargaining can effectively curb the irrational competition between migrant workers and enhance their right to speak in wage negotiations, while improving the bargaining power of migrant workers.

\section{Government and Policy Support}

As labor unions have limitations, the wages of workers largely depend on the government and relevant departments for increase. According to Zeng Fanqiang, chairman of the general labor union of Guangzhou, experience of many years with great successes show that the local government and other relevant units are greatly important, the migrant workers' problems are generally handled well, and the rights and interests of migrant workers are maintained at a good level (Xinhua News, 2011). The minimum wage standard of the government covers vulnerable groups such as migrant workers. The Guangdong Provincial Federation of Labor Unions has vigorously promoted industry-regional collective contract systems in recent years. Many companies have signed a collective contract. Relevant laws, regulations, and institutional policies provide protection to migrant workers regarding their wages as well as provide a legal system base for the bargaining power of migrant workers in terms of wages and employment.

\section{FUZZY EVALUATION APPROACH OF THE BARGAINING POWER}

In the previous section, we discussed the factors that enhance the bargaining power of migrant workers. However, a question remains: Do these factors have the same effects? How is the total bargaining power of migrant workers? Therefore, the effects of each factor need further analysis. The evaluation of the bargaining power of migrant workers is the result of the vague subjective consciousness of the people, and the analysis of factors that enhance the bargaining power of migrant workers is even more unclear. The vagueness of these factors has prevented us from conducting an evaluation using simple scores. Zadeh (1965) first introduced the fuzzy set theory which was oriented to the rationality of uncertainty due to imprecision or vagueness. The AHP was developed in the 1970s by Saaty. The analytic hierarchy process method combines qualitative and quantitative analyses effectively, keeping the model systematic and rational as well as enabling decision makers to fully utilize their experience and judgment for mathematical decision making. Therefore, this paper proposes to expand the AHP processes to a fuzzy environment and build a fuzzy comprehensive evaluation model based on it.

\section{Building a Hierarchical Structure of Evaluation Index System}

Indexes chosen for evaluation should be as comprehensive and complete as possible, so that the nature and determinant of bargaining power of migrant workers can be reflected from every aspect. In addition, indexes themselves should be theoretically systematic and practically manageable. Based on previous analysis, we build a hierarchical structure of evaluation index system here. 


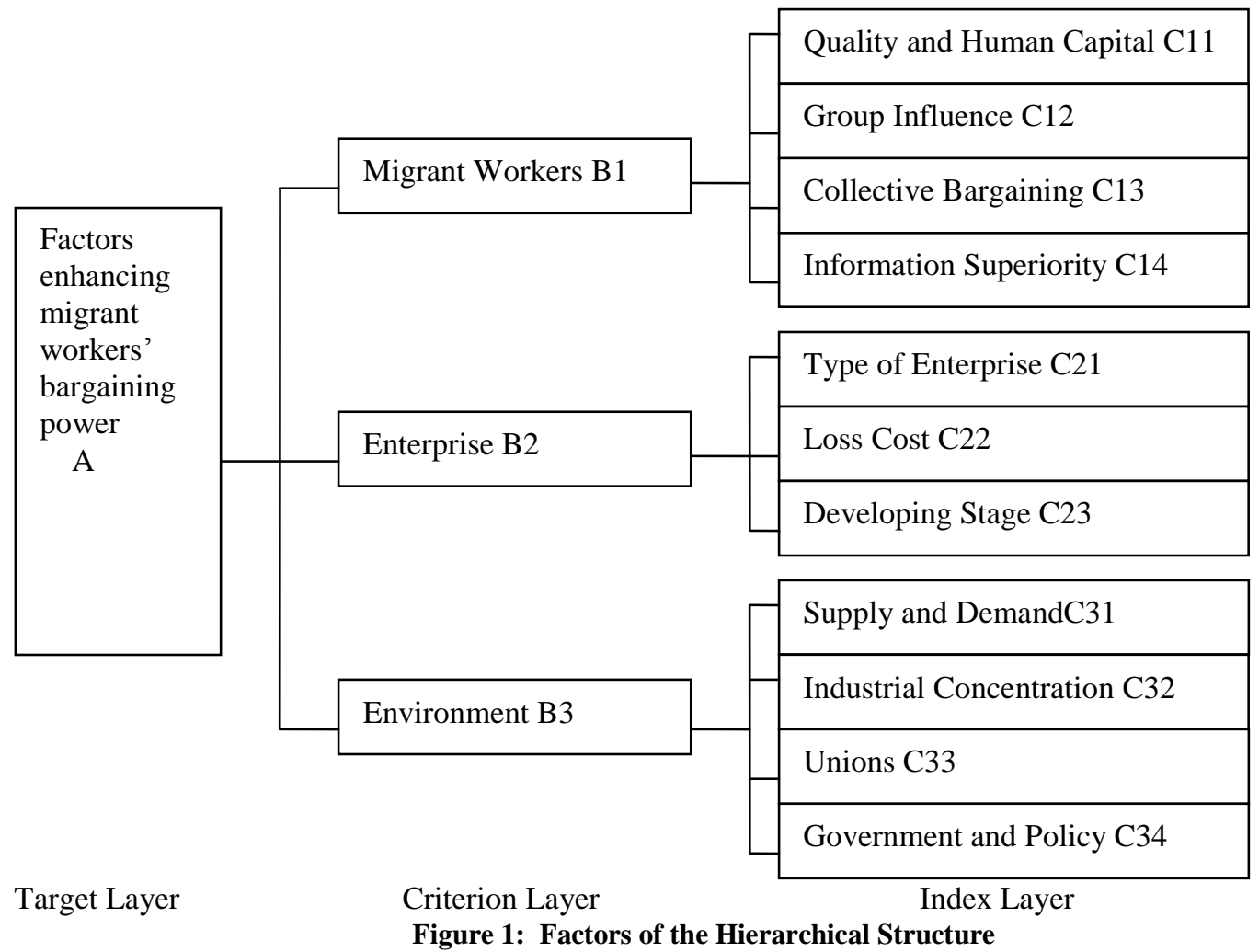

\section{Determining Factor Weight by AHP}

In the AHP, let $\mathrm{B}=$ (bij) be an $\mathrm{n} \times \mathrm{n}$ matrix of pair-wise comparisons, where bij $>0$, bij $=1 / \mathrm{bji}$, for all $1 \leq$ $\mathrm{i}, \mathrm{j} \leq \mathrm{n}$, thus $\mathrm{B}$ is called a judging matrix. In the constitution of the judging matrix, to get rid of the subjective factors, experts are asked to grade the importance between each index and each criterion in the index system. Then we can calculate the weights. A total of 25 respondents that include research experts on migrant workers, professors, employers, and migrant workers themselves were selected. These respondents conducted a pair-wise comparison between the enhancing factors and developed a judgment matrix to determine the relative importance of the various factors in the hierarchy. Moreover, these respondents evaluated the various factors, that is, the strength of each factor. Because space is limited, we omitted the tedious formula and procedure, and only present the resultant data in Tables 2-6.

Table 2: A-B Judgment Matrix, Weight, and Consistency Test

\begin{tabular}{lccccc}
\hline \multicolumn{1}{c}{ A } & B1 & B2 & B3 & Weight & 入 $\max$ \\
\hline B1 & 1 & 5 & 4 & 0.665 & \\
B2 & $1 / 5$ & 1 & $1 / 3$ & 0.056 & 3.073 \\
B3 & $1 / 4$ & 3 & 1 & 0.187 & \\
Consistency Test & $\mathrm{CI} / \mathrm{RI}=0.037 / 0.58=0.063<0.1$ & & & \\
\hline
\end{tabular}

Table 3: B1-C1 Judgment Matrix, Weight, and Consistency Test

\begin{tabular}{|c|c|c|c|c|c|c|}
\hline B1 & C11 & $\mathrm{C12}$ & $\mathrm{C13}$ & $\mathrm{C14}$ & Weight & 入max \\
\hline C11 & 1 & 5 & 3 & 3 & 0.518 & \multirow{5}{*}{4.151} \\
\hline $\mathrm{C} 12$ & $1 / 5$ & 1 & $1 / 2$ & 2 & 0.133 & \\
\hline $\mathrm{C} 13$ & $1 / 3$ & 2 & 1 & 4 & 0.252 & \\
\hline $\mathrm{C} 14$ & $1 / 3$ & $1 / 2$ & $1 / 4$ & 1 & 0.094 & \\
\hline Consistency Test & $\mathrm{CR}=\mathrm{CI}$ & $5 / 0.96$ & $<0.1$ & & & \\
\hline
\end{tabular}


Table 4: B2-C2 Judgment Matrix, Weight, and Consistency Test

\begin{tabular}{|c|c|c|c|c|c|}
\hline B2 & $\mathrm{C21}$ & $\mathrm{C22}$ & $\mathrm{C23}$ & Weight & 入max \\
\hline $\mathrm{C} 21$ & 1 & 4 & 5 & 0.680 & \multirow{4}{*}{3.023} \\
\hline $\mathrm{C} 22$ & $1 / 4$ & 1 & 2 & 0.201 & \\
\hline $\mathrm{C} 23$ & $1 / 5$ & $1 / 2$ & 1 & 0.117 & \\
\hline Consistency Test & $\mathrm{CR}=\mathrm{CI} / \mathrm{R}$ & $8=0$ & & & \\
\hline
\end{tabular}

Table 5: B3-C3 Judgment Matrix, Weight, and Consistency Test

\begin{tabular}{|c|c|c|c|c|c|c|}
\hline B3 & C31 & $\mathbf{C 3 2}$ & C33 & C34 & Weight & 入max \\
\hline $\mathrm{C} 31$ & 1 & 5 & 7 & 5 & 0.608 & \\
\hline $\mathrm{C} 32$ & $1 / 5$ & 1 & 4 & 3 & 0.221 & 4.166 \\
\hline $\mathrm{C} 33$ & $1 / 7$ & $1 / 4$ & 1 & $1 / 2$ & 0.064 & \\
\hline $\mathrm{C} 34$ & $1 / 5$ & $1 / 3$ & 2 & 1 & 0.106 & \\
\hline Consistency Test & \multicolumn{6}{|c|}{$\mathrm{CR}=\mathrm{CI} / \mathrm{RI}=0.055 / 0.96=0.058<0.1$} \\
\hline
\end{tabular}

\begin{tabular}{lccccccc} 
Indicators & $\begin{array}{c}\text { Very Strong } \\
\text { (No.) }\end{array}$ & $\begin{array}{c}\text { Strong } \\
\text { (No.) }\end{array}$ & $\begin{array}{c}\text { Relatively } \\
\text { Strong (No.) }\end{array}$ & $\begin{array}{c}\text { Medium } \\
\text { (No.) }\end{array}$ & $\begin{array}{c}\text { Relatively } \\
\text { Weak (No.) }\end{array}$ & $\begin{array}{c}\text { Weak } \\
\text { (No.) }\end{array}$ & $\begin{array}{c}\text { Very Weak } \\
\text { (No.) }\end{array}$ \\
\hline C11 & $0.32(8)$ & $0.48(12)$ & $0.08(2)$ & $0.12(3)$ & 0 & 0 & 0 \\
C12 & $0.12(3)$ & $0.28(7)$ & $0.4(10)$ & $0.12(3)$ & $0.08(2)$ & 0 & 0 \\
C13 & $0.28(7)$ & $0.4(10)$ & $0.12(3)$ & $0.16(4)$ & $0.04(1)$ & 0 & 0 \\
C14 & $0.08(2)$ & $0.2(5)$ & $0.32(8)$ & $0.2(5)$ & $0.12(3)$ & $0.08(2)$ & 0 \\
C21 & $0.32(8)$ & $0.32(8)$ & $0.08(2)$ & $0.12(3)$ & $0.08(2)$ & 0 & $0.08(2)$ \\
C22 & $0.16(4)$ & $0.12(3)$ & $0.36(9)$ & $0.2(5)$ & $0.08(2)$ & $0.08(2)$ & 0 \\
C23 & 0 & $0.24(6)$ & $0.12(3)$ & $0.4(10)$ & $0.12(3)$ & $0.08(2)$ & $0.04(1)$ \\
C31 & $0.32(8)$ & $0.28(7)$ & $0.12(3)$ & $0.2(5)$ & $0.08(2)$ & 0 & 0 \\
C32 & $0.2(5)$ & $0.28(7)$ & $0.32(8)$ & $0.16(4)$ & $0.04(1)$ & 0 & 0 \\
C33 & $0.12(3)$ & $0.08(2)$ & $0.2(5)$ & $0.36(9)$ & $0.16(4)$ & $0.08(2)$ & $0.08(2)$ \\
C34 & $0.08(2)$ & $0.12(3)$ & $0.4(10)$ & $0.2(5)$ & $0.12(3)$ & $0.04(1)$ & $0.08(2)$ \\
\hline
\end{tabular}

Fuzzy Comprehensive Evaluation

The fuzzy comprehensive evaluation Bij of the criterion layer is calculated by:

$\mathrm{Bi}=\mathrm{Ai} \times \mathrm{Ri}$

where $\mathrm{Ai}$ is the weight of $\mathrm{Bi}$ and $\mathrm{Ri}$ is the fuzzy evaluation matrix of $\mathrm{Bi}$; The fuzzy comprehensive evaluation of the target layer is set by:

$\mathrm{B}=\mathrm{A} \times \mathrm{R}$

where $\mathrm{A}$ is the weight of $\mathrm{B}$ and $\mathrm{R}$ is the fuzzy evaluation matrix of $\mathrm{Bi}$. Each comment in the reviews is given a standard score $\{95,85,75,65,55,45,35\}$, and then the fuzzy evaluation score of the enhancing factors of the bargaining power is obtained (Du, 2005). The final evaluation results are presented in Tables 7 and 8.

Table 7: Second-Level Indicators of First-Level Evaluation Vector

\begin{tabular}{|c|c|c|c|c|c|c|c|c|}
\hline Second-Level Indicators & Weight & $\mathbf{b}_{\mathrm{i} 1}$ & $\mathbf{b}_{\mathrm{i} 2}$ & $\mathbf{b}_{\mathrm{i} 3}$ & $\mathbf{b}_{\mathbf{i} 4}$ & $\mathbf{b}_{\mathrm{i5}}$ & $\mathbf{b}_{\mathrm{i} 6}$ & $\mathbf{b}_{\mathrm{i} 7}$ \\
\hline $\mathrm{C} 11$ & 0.518 & \multirow{4}{*}{0.260} & \multirow{4}{*}{0.405} & \multirow{4}{*}{0.155} & \multirow{4}{*}{0.137} & \multirow{4}{*}{0.032} & \multirow{4}{*}{0.008} & \multirow{4}{*}{0.000} \\
\hline $\mathrm{C} 12$ & 0.133 & & & & & & & \\
\hline $\mathrm{C} 13$ & 0.252 & & & & & & & \\
\hline $\mathrm{C} 14$ & 0.094 & & & & & & & \\
\hline $\mathrm{C} 21$ & 0.680 & \multirow{3}{*}{0.250} & \multirow{3}{*}{0.270} & \multirow{3}{*}{0.153} & \multirow{3}{*}{0.169} & \multirow{3}{*}{0.085} & \multirow{3}{*}{0.025} & \multirow{3}{*}{0.059} \\
\hline $\mathrm{C} 22$ & 0.201 & & & & & & & \\
\hline $\mathrm{C} 23$ & 0.117 & & & & & & & \\
\hline C31 & 0.608 & \multirow{4}{*}{0.254} & \multirow{4}{*}{0.250} & \multirow{4}{*}{0.199} & \multirow{4}{*}{0.201} & \multirow{4}{*}{0.080} & \multirow{4}{*}{0.009} & \multirow{4}{*}{0.014} \\
\hline $\mathrm{C} 32$ & 0.221 & & & & & & & \\
\hline C33 & 0.064 & & & & & & & \\
\hline $\mathrm{C} 34$ & 0.106 & & & & & & & \\
\hline
\end{tabular}


Table 8: Comprehensive Evaluation Vector

\begin{tabular}{lcccccccc}
\hline \multicolumn{1}{c}{ First-Level Indicators } & Weight & $\mathbf{b}_{\mathbf{1}}$ & $\mathbf{b}_{\mathbf{2}}$ & $\mathbf{b}_{\mathbf{3}}$ & $\mathbf{b}_{\mathbf{4}}$ & $\mathbf{b}_{\mathbf{5}}$ & $\mathbf{b}_{\mathbf{6}}$ & $\mathbf{b}_{\mathbf{7}}$ \\
\hline Migrant workers & 0.665 & & & & & & & \\
Enterprises & 0.056 & 0.234 & 0.331 & 0.149 & 0.108 & 0.024 & 0.008 & 0.006 \\
Environment & 0.187 & & & & & & & \\
\hline
\end{tabular}

The evaluation set is changed to the rating scores vector, i.e., $Z=\{95,85,75,65,55,45,35\}$. The final score of all the factors can then be calculated by:

$\mathrm{H}=\mathrm{B} \times \mathrm{ZT}$

where $\mathrm{B}$ is fuzzy comprehensive evaluation vector and ZT is the transportation of the rating scores vector $\mathrm{Z}$. Score of migrant workers: $\mathrm{H} 1=\mathrm{B} 1 \times \mathrm{ZT}=(0.260,0.405,0.155,0.137,0.032,0.008,0.000) \times(95,85,75,65,55,45,35) \mathrm{T}$ $=81.8$ points. Score of enterprises: $\mathrm{H} 2=\mathrm{B} 2 \times \mathrm{ZT}=(0.250,0.270,0.153,0.169,0.085,0.025,0.059) \times(95,85,75$, $65,55,45,35) \mathrm{T}=77.03$ points. Score of environment: $\mathrm{H} 3=\mathrm{B} 3 \times \mathrm{ZT}=(0.254,0.250,0.199,0.201,0.080,0.009$, $0.014) \times(95,85,75,65,55,45,35) \mathrm{T}=78.67$ points. We can obtain the final score of the bargaining power of migrant workers, with $\mathrm{H}=\mathrm{B} \times \mathrm{ZT}=(0.234,0.331,0.149,0.108,0.024,0.008,0.006) \times(95,85,75,65,55,45,35)$ $\mathrm{T}=70.45$ points. The bargaining power of migrant workers is between medium ( 65 points) and strong ( 75 points) and is biased in favor of the medium.

Based on the results of the factors enhancing the bargaining power of migrant workers, the migrant workers obtained the highest score of 81.8 points. This result indicates that the change in migrant workers is the direct factor or variable that enhances their bargaining power. The overall score of the bargaining power of migrant workers is approximately 70.45 points at the medium level. Therefore, their bargaining power needs improvement.

\section{DISCUSSION}

Based on the results, the migrant workers themselves are the most important factor in promoting their bargaining power. The reason for this is the generational change in migrant workers and the change in their mentality. The main force of migrant workers is the so-called second-generation migrant workers, whose age range is from 17 to 30 years old. The qualifications and skills of the new generation of migrant workers have been improved to a certain extent with more job choices, but these workers are not interested in general work and manual jobs. A gap exists in the supply of ordinary labor in manufacturing and labor-intensive enterprises. The case in which supply is less than the demand increases the bargaining power of migrant workers, which is inevitable. Migrant workers pay more attention to long-term interests and "spillover" effects of work, which include the enhancement of the opportunity to learn technical skills and welfare conditions, the possibility of integration into the city after completing their education, and the possibility of having a comprehensive quality of life. The internal structural changes among migrant workers enable the changes in the employment structure of migrant workers, thus affecting the supply and demand in the labor market and becoming a cause for concern on the part of businesses, labor unions, and the government. From this perspective, the migrant workers are the fundamental factor that enhances their own bargaining power.

The enhancement of the bargaining power of migrant workers benefits from their relatively high education, enhanced sense of collective bargaining, and increasing influence as a group. The improvement of the bargaining power, social status, rights, and interests of migrant workers can better protect labor rights and enhance the migrant workers upward potential, promoting their human capital. In this paper, the positive effect of the enhancement of the bargaining power of migrant workers is summarized as follows. First, migrant workers safeguard their rights and interests. The serious imbalance between supply and demand in the labor market in China has existed for a long time. The right of migrant workers to speak for their own interests has been in a weak position under the premise of the supply and demand imbalance (Qin, 2009). Employers take advantage of their dominant position in the labor market and drive down the wage of migrant workers. With the enhancement of the bargaining power of migrant workers, the situation that companies unilaterally decide the wage has been limited and migrant workers can now safeguard their own interests to a certain extent. Second, the enhancement of the bargaining power of migrant workers and their increasing job autonomy has caused the adjustment in the industrial structure. The natural turnover 
of the labor market appears sharp: the new generation of migrant workers is becoming the main component of the labor market in China. The choices of work and concepts of choosing jobs of these new-generation workers are different from those of their parents. They understand that the primary assembly line work cannot meet their needs. The concept of "shortage of migrant workers" is a reflection of objective reality, positively stimulating the economic development of China and forcing coastal areas and the Mainland to accelerate the transformation and upgrading of Chinese industries. Third, the improvement of the bargaining power of migrant workers promotes labor unions and the regulations of collective bargaining for better implementation. In the 12th five-year planning framework of China, collective bargaining is regulated to promote collective wage negotiations and form a kind of wage determination and growth mechanism that reflects business benefits and the relationship between supply and demand in the market. Several regions and enterprises have formed the atmosphere of collective wage negotiations and labor unions at all levels. Workers consider the wage collective negotiations as the key work in coordinating labor relations and safeguarding their own rights and interests to promote wage collective negotiations.

The open vision of the new generation of migrant workers provides them with more power in the bargaining game with enterprises. However, enhancing the bargaining power of the former is accompanied by several negative aspects.

Firstly, the wage growth can be unhealthy for the economy if it is not managed and balanced effectively. According to statistics from 2001 to 2009, a mutation process was noted in the changes in the wages of migrant workers. From 2001 to 2005, the average annual growth rate of wages for migrant workers was only 4.8 percent, whereas in 2006 alone, the annual per capita wages of migrant workers increased to 12,240 yuan from 6,577 yuan in 2005 , a growth rate of 86.1 percent. Until 2009, the average annual wage growth rate remained at 12.97 percent (Zou, 2012). The substantial increase in wages for migrant workers in 2006 can be attributed to the emergence of the "shortage of migrant workers." The fight for the wage increase of migrant workers merely relies on the withdrawal from the labor market. In a socialist country such as China, the situation is clearly unhealthy, causing stagnant production resulting from underemployment. This situation is slowing down urbanization in China, which is not conducive to the social and economic development of the country.

Secondly, human capital accumulation is insufficient because of temporary employment of migrant workers. The "migrant workers' employment trends report" released by Tsinghua University indicates that the temporary employment trend of migrant workers intensified these years, with the average work of migrant workers lasting 3.8 years in the early 2000s, while it was 1.4 years in 2008 (Fu, 2012). "Day laborers" are linked to the meticulous division of labor in the Taylor system, which does not enable migrant workers to improve their wages by developing their own skills through long-term work. Most migrant workers do not possess accumulated knowledge about technology and cannot increase wages by changing companies. On the contrary, frequent transfers from enterprise to enterprise make migrant workers unable to enjoy the benefits of social and medical insurance and other social security system benefits.

Thirdly, the labor cost of small businesses increases. The phenomena of "labor shortage" and "strikes" have enhanced the bargaining power of migrant workers: employers can no longer hire workers as they wish and are required to raise wages and improve the welfare of migrant workers. In 2010, around 84 percent of the 450,000 employees in Shenzhen Foxconn factory realized their demand for a salary adjustment. Thus, the monthly base salary of Shenzhen factory employees increased to 415.8 million yuan, which is approximately 60 billion a year (Ningbo Network, 2010). This figure would be disastrous for coastal processing enterprises that rely on low labor costs. Except for the auto parts production and assembly industries, no pay increase has been provided to processing enterprises employees. These enterprises belonging to the low-end chain have no power to bargain with international capital.

\section{PRACTICAL IMPLICATIONS}

Changes in the bargaining power of Chinese migrant workers are influenced by different factors. In this study, we mainly predicted the changes that would take place based on the following factors: the supply and demand of Chinese migrant workers and the quality of Chinese migrant workers; the employment system, structural upgrading, and technological progress of Chinese enterprises; and the education system in China and the related 
policies and regulations released by the Chinese government. This paper also analyzed the micro (i.e., Chinese migrant workers), meso (i.e., Chinese enterprises), and macro (i.e., the Chinese government and labor unions) levels to present a conclusion.

First, 24 provinces in China are raising the minimum wage standard in 2013. This action safeguards the rights and interests of workers and reduces the wage gap to enable ordinary workers to enjoy the fruits of the economic reforms and opening. Related to the state of "shortage of migrant workers" or short supply of Chinese migrant workers, increasing the wages is the only way to attract them to work. In recent years, ordinary labor supply in China has been exhibiting a downward trend in terms of growth. In the 1990s, the annual labor increase in China was between 10 million and 20 million, whereas the growth rate of the past two years was only in a few millions (Xinhua Net, 2011). This phenomenon can be attributed to the birth control policy of China. Birth restrictions have led to a corresponding control in the rural population. However, among the consequences of such policy is the reduction of the number of the rural labor force. With the improvement of the education level of migrant workers in China, their employment structure has also changed, with the number of migrant workers in the low-end production dwindling. In the "seller's market" caused by the "shortage of migrant workers," the short supply of migrant workers continues to enhance their bargaining power.

Second, from the perspective of Chinese enterprises, the main employment system in China is the labor contract system. The employment of enterprises is the full implementation of the labor contract system. With the help of labor unions, migrant workers can sign collective contracts with employers to protect their basic rights. The industrial structure of China is escalating the changes in labor-intensive industries because of technological advances. The presence of more machines instead of human labor seems to weaken the capacity of migrant workers to negotiate with enterprises. However, the role of migrant workers should not be overlooked, particularly in the services industry, which is in urgent need of such workers. In this case, the bargaining power of migrant workers still has room for improvement.

Third, the current education system in China continues to undergo reforms, including the implementation of the nine-year compulsory education. The government strongly advocates popularizing the nine-year compulsory education so that rural children can enjoy free compulsory education and no longer have to drop out of school because of the inability to pay school fees. Therefore, the state supports poor rural and college students to complete their studies by granting loans. Such programs provide opportunities to rural children to obtain an education, which plays an important role in their bargaining power when they become workers. Moreover, local governments continue to increase the minimum wage standard to protect the rights and interests of laborers. These policies and regulations protect the legitimate rights and interests of migrant workers, providing a legal basis for migrant workers when they bargain with employers.

Our analysis indicates that the change in the bargaining power of Chinese migrant workers is influenced by factors such as education level and policy support. However, certain factors such as technological progress in enterprises weaken the bargaining power of migrant workers. In general, the economic development and optimization of industrial structure upgrading in China, as well as the improvement of the educational level and technical experience of Chinese migrant workers, can further improve the bargaining power of Chinese migrant workers.

\section{RECOMMENDATIONS}

Although the bargaining power of migrant workers has improved, this paper concludes that the bargaining power of migrant workers is only 70 points, which is at the medium level. Even in a "seller's market" caused by the so-called "shortage of migrant workers," the bargaining power of migrant workers remains low. If in a rare case of a "seller's market," the wage bargaining power of migrant workers, as well as their social status and rights, has not been fundamentally improved, then this situation places migrant workers at a disadvantage. We discussed in the previous sections of this paper that the positive role of the enhancement of the bargaining power of migrant workers is greater than the negative effect. We predicted that the bargaining power of migrant workers would further improve. Therefore, we should take the needed measures and suggestions to promote the further improvement of the bargaining power of migrant workers. However, the relationship between employees and employers is not only 
concerned about the interests of migrant workers but also considers the reasonable interests of enterprises. Therefore, the government and labor unions should not stand by idly. The four sectors should cooperate and achieve a situation that will benefit all sectors concerned.

\section{Migrant Workers}

As for the factors that enhance the bargaining power of Chinese migrant workers, the factor of the Chinese migrant workers themselves influences the enhancement of their bargaining power most. Therefore, the intrinsic value of Chinese migrant workers has a great influence on their bargaining power. Intrinsic value depends on the qualities of a person, such as those related to skills, knowledge, and experience. Chinese migrant workers must improve themselves to enhance their bargaining power through receiving education, getting skillful training, and achieving stabile work to enhance their own human capital. On one hand, knowledge and skills accumulation enable Chinese migrant workers to become mature workers even scarce workers which play a positive effect on enhancing their bargaining power in labor-intensive industries; on the other hand, high levels of education and skills also enable migrant workers to increase their competitiveness with other labor force in such industries where migrant workers' bargaining power is relatively weak. In addition, Chinese migrant workers cannot achieve collective rationality because of the lack of the sense of collective cooperation. Chinese migrant workers should safeguard their own interests and rights through horizontal integration and conscious cooperation or strengthen the awareness of protecting their rights by law.

\section{Enterprises}

The bargaining power enhancement of Chinese migrant workers is the trend of the future development of enterprises. The process of employment is a transaction process between labor capital and physical capital. This process is accompanied by another process that the value of labor force is fully displayed and admitted; workers themselves realize the value of their human capital progressively. When the bargaining power between the enterprise and its employee's changes, wise enterprise should re-adjust the relationship between interests and allocation, raise the wages, improve the working environment, and reinforce the incentives in accordance with the change in bargaining power. Enterprises should also keep an active attitude toward the enhancement of the bargaining power of employees instead of having a negative attitude to prevent the upgrading of the bargaining power of employees. However, the bargaining game involving employers and employees should achieve balance; any party with too strong a bargaining power will affect the rational development of the labor market.

\section{Labor Unions}

Labor unions act as the beneficial representative of workers, some scholars called them "collective speaking system" (Ronald \& Robert, 1999), the intention of labor unions is to change the weak position of workers and use organizational strength to maintain workers' rights, labor union is the precondition of collective bargaining. The western countries generally establish the collective bargaining system to handle labor conflicts and collective bargaining has become the main means of adjusting labor relations under the conditions of market economy. However, most of Chinese migrant workers lack of "beneficial spokesman", leading not to compete with employers by collective strength. There are more than one million migrant workers in China that are out of reach the labor unions, the setting up rate of labor union is lower in non-public enterprises and the membership rate only reached $32 \%$, by the end of 2010 . There were about five million workers signing wages special collective contract with the company in Guangdong province, while there were about 26 million staffs totally (Zhang \& Wu, 2010).

\section{Government}

Generally speaking, a country's institutional factors produce great influence for their workers' wage bargaining. In China, urban-rural dual system of the "hukou" registration system (rural registered permanent residence and urban registered permanent residence isolation) and the social security system (the social security of city residents is more perfect than the rural residents) play a great effect on Chinese migrant workers' wage bargaining. The government should speed up the system reform, especially the urban-rural dual structure of the "hukou" system, which is the cause of differences in wage, education, housing, medical care, and other aspects 
between the Chinese migrant workers and city residents, and it also indirectly affects the labor employment system, social security system and public service system. Therefore, to promote the Chinese migrant workers working in the city and improve the weak position of Chinese migrant workers, and to ultimately improve the bargaining power of Chinese migrant workers, the government should make great efforts to strip various welfare system behind the "hukou" system, establish a unified household registration system, unified urban-rural labor market system and unified social security system.

\section{LIMITATIONS AND FUTURE RESEARCH}

In this paper, we refined the enhancing factors for the bargaining power of Chinese migrant workers through a review of existing literature, analyzing the available data, and primary research by conducting interviews. Several other factors were not discussed in this paper, but we intend to expand the range and the number of enhancing factors in a follow-up study. Moreover, because of the different economic development between different regions and labor markets, the bargaining power of migrant workers in this region differs from that of migrant workers in other regions. This paper did not conduct a rigorous regional distinction. In future research, we will distinguish regional differences and carry out an inter-regional comparative study to further tap the value and significance of this kind of research.

\section{ACKNOWLEDGEMENT}

This research is funded by Humanities and Social Sciences Planning Fund Supported by Chinese Ministry of Education (10YJA630052) (11YJA630073).

\section{AUTHOR INFORMATION}

Han Ping is an Associate Professor of Organizational Behavior and Human Resource Management at The School of Management in Xi' an JiaoTong University, P.R. China. In 2008, Han Ping went to Brigham Young University as a visiting scholar for further study. Han Ping is the author and coauthor of three professional books and almost thirty articles dealing with leadership, organizational behavior, organization analysis and evaluation. She has provided consultation for more than ten corporations and government agencies dealing with management. Besides, she has participated in two National Science Foundation projects of China and two Humanities and Social Sciences projects of The Ministry of Education. This diverse experience has provided her many insights in management, human resource, leadership, organization etc. E-mail: hpca@mail.xjtu.edu.cn

Bahaudin G. Mujtaba is Professor of Management and Human Resources at Nova Southeastern University's H. Wayne Huizenga School of Business and Entrepreneurship. Bahaudin is the author and coauthor of several professional and academic books dealing with diversity, business ethics, leadership, and management. During the past twenty-five years he has had the pleasure of working with human resource professionals, researchers, and managers in the United States, Brazil, Bahamas, Afghanistan, China, Pakistan, St. Lucia, Grenada, India, Japan, Thailand, Malaysia, Cambodia, Vietnam, and Jamaica. This diverse exposure has provided him many insights in ethics, culture, and management from the perspectives of different firms, people groups, and countries. E-mail: mujtaba@nova.edu (Corresponding author)

Chen Xue, The School of Management, Xi'an Jiaotong University, P. R. China. Chen Xue is a Master of Human Resource at The School of Management in Xi'an Jiaotong University. She is the coauthor of three articles dealing with turnover, stress and job satisfactory. She has participated in two Humanities and Social Science projects subsidized by The Ministry of Education, P. R. China. E-mail: chenxue7726@stu.xjtu.edu.cn

\section{REFERENCES}

1. Bental B., \& Demougin, D. (2010). Declining labor shares and bargaining power: An institutional explanation. Journal of Macroeconomics, 32, 443-456.

2. Berg R. G. I., \& Smith R. (1999). Modern labor economics. Beijing: Renmin University of China press, p. 487. 
3. Cahuc, P., Postel-Vinay, F., \& Robin, J. M. (2006). Wage bargaining with on-the-job search: theory and evidence. Econometrica, 74(2): 323-364.

4. Cheng, C., \& Fuzhong, C. (2011). The impact of labor union on wage income based on institution factor perspective: empirical evidence from UK. Contemporary Economy \& Management, 33(4): 5-10.

5. Dong, D. (2005). The modern comprehensive evaluation methods and selecting cases. Beijing: Tsinghua University Press, 147-148.

6. Dutt, A. M., \& Sen, A. (1997). Union bargaining power, employment, and output in a model of monopolistic competition with wage bargaining. Journal of Economics, 65(1): 1-17.

7. Fagre, N., \& Wells Jr., L. T. (1982). Bargaining power of multination's and host governments. Journal of International Business Studies, 13(2): 9-23.

8. Guanghua S., \& Guilan Y. (2003). An analysis on factors affecting the negotiation power of human capital. Management Review, 15(7): 58-62.

9. Hoaxing, Z., \& Jun, W. (2010). Corporate profits doubled, migrant workers' income did not rise. Xinhua Net. Retrieved from http://news.gd.sina.com.cn

10. Ke, Z., \& Houjun, W. (2009). Comparison of moving motivation and career expectations between two generations migrant workers. Statistics and Decision, 16: 88-90.

11. Leap, T. L., \& Grigsby, D. W. (1986). A conceptualization of collective bargaining power. Industrial and Labor Relations Review, 39(2): 202-213.

12. Lijuan, Q. (2009). Research on migrant workers' wage level and its decision mechanism of current China. Master's thesis of Hu Nan Technological University.

13. Macleds, W. B., \& Malcomson, J. M. (1993) Wage premiums and profit maximization in efficiency wage models. European Economic Review, 37(6): 1223-1249.

14. Ming, L. (2004). Bargaining theory of wages and employment: the efficiency of the dual employment system in China. Shanghai People Press.

15. Minimum wage standard (2012). Retrieved from http://sh.sina.com.cn/news/g/2012-12-28/155127770.html

16. Mujtaba, B. G. (2014). Managerial skills and practices for global leadership. ILEAD Academy: Florida.

17. Ningbo Net (2010). The salary increase tidal enhances migrant workers' bargaining power and the layout of manufacturing industries has changed. Retrieved from http://www.cnnb.com.cn

18. Oxford Economic Report (2010). Chinese workers' bargaining power is enhancing. Retrieved from http://finance.qq.com/a/20100810/006876_1.html

19. Pacitti, A. N. (2009). Inflation in the United States: Bargaining labor market institutions and the Phillips curve. Washington, D.C: American University.

20. Pengrong, Z. (2002). Bargaining power between the boss and the employee. Territory Economy, 11: 19-21.

21. Shi, S. (1995). Money and prices: a model of search and bargaining. Journal of economic theory, 67: 467496.

22. Ping, H., Mujtaba, B. G., Whetten, D. A., \& Wei, Y. (2012). Leader personality characteristics and upward trust: A study of employee-supervisor dyads in China. Journal of Applied Business Research, 28(5): 10011016.

23. Svejnar, J. (1986). Bargaining power, fear of disagreement, and wage settlements: Theory and evidence from U.S. industry. Econometrica, 54(5): 1055-1078.

24. Wenliang, Z. \& Bingshen, Z. (2005). Bargaining power of human capital in migrant workers and its governance. Contemporary Finance, 8: 9-12.

25. Weigang, F. (2012). How to treat the "bra cero" of migrant workers. Retrieved from www.nddaily.com Southern Metropolis Daily Mark.

26. Xinhua Net (2011). Observers claim "labor shortage" reflect the conceptual changes of migrant workers. Retrieved from http://news.sina.com.cn/c/2011-02-14/194521952957.shtml

27. Xinxin, X. (2008). An empirical study of wage determination mechanism differences between the state sector and the non-state sector in China. Industrial Economic Review, 7(1): 60-81.

28. Yankow, J. J. (2006). Why do cities pay more? An empirical examination of competing theories on the urban wage premium. Journal of Urban Economics, 60(2): 139-161.

29. Yao, Z. (2012). The formation mechanism of the income of migrant workers. Retrieved from http://www.chinareform.org.cn/Economy/Agriculture/Forward/201207/t20120702_145699.htm

30. Zadeh, L. A. (1965). Fuzzy sets. Information and Control, 8: 338-353.

31. Zhiban, W. (2012). Writings. Retrieved from http://info.gongchang.com/a/main-2012-02-11-440068.html 